Iwona Imańska

Toruń

\title{
Kilka uwag i spostrzeżeń o katalogach aukcyjnych jako źródle do badań księgozbiorów prywatnych
}

O znaczeniu dawnych katalogów bibliotecznych jako źródeł do badań nad dziejami książki, szczególnie nad historią bibliotek, polscy i zagraniczni badacze pisali już kilkakrotnie ${ }^{1}$. Jednym z rodzajów katalogów bibliotecznych są katalogi aukcyjne, zaliczane również do katalogów księgarskich. Dla osób badających kolekcjonerstwo książek w dawnych wiekach spośród katalogów aukcyjnych przydatne są przede wszystkim te spisy, które rejestrowały bibliotekę prywatną wystawioną na publiczną sprzedaż.

Katalogów aukcyjnych rejestrujących księgozbiory prywatne z okresu staropolskiego zachowało się do dziś wcale niemało. Jest to związane ze sporą popularnością tego sposobu zbywania księgozbiorów w niektórych miastach polskich w tych czasach. Aukcje bowiem jako publiczna sprzedaż książek, zapoczątkowane w Lejdzie w 1599 r., a stosowane na dużą skalę w wielu krajach europejskich od połowy XVII w., w Rzeczypospolitej były urządzane od 1672 r., początkowo tylko w Gdańsku, gdzie do końca tego stulecia przeprowadzono nie mniej niż 46 licytacji książkowych. Od drugiego dziesięciolecia XVIII wieku sięgnięto po licytacje w celu sprzedaży książek w kolejnych miastach Prus Królewskich: w Toruniu (1716), Elblagu (1717) i Malborku (1718). W Warszawie pierwsza aukcja książek została zorganizowana na początku stycznia $1761 \mathrm{r}$., a jej przedmiotem były dublety z książnicy braci Załuskich. Kolejne miasta dawnej Rzeczypospolitej do wymienionych ośrodków dołączyły dopiero w ostatnich latach XVIII wieku, i to często już w innej sytuacji politycz-

${ }^{1}$ Między inymi: Jadwiga Rudnicka, Dawne katalogi księgarskie jako źródło do dziejów ksiażki, ,,Rocznik Biblioteki Narodowej”, 7:1971, s. 377-393; Barbara Bieńkowska, Inwentarze księgozbiorów prywatnych jako źródla do badań nad dziejami czytelnictwa, „,Studia o Książce”, 18:1989, s. 65-76; Krzysztof Migoń, Dawne katalogi biblioteczne jako źródło wiedzy o kulturze ksiażki, ,, Roczniki Biblioteczne”, 49:2005, s. 301-310. 
nej. Były to m. in. Lwów, Kraków, Leszno, Wilno i Poznań2. W sumie od roku 1672 do 1800 na ziemiach polskich przeprowadzonych zostało nie mniej niż 690 licytacji, z czego w wypadku 361 przedmiotem aukcji były księgozbiory prywatne (prócz tego licytowano dublety z bibliotek publicznych, zasoby księgarni i zbiory różnego pochodzenia). Na 361 licytacjach wyprzedawane były zbiory zgromadzone przez 324 właścicieli. Różnica w liczbach wynika z tego, że niektóre biblioteki osiagnęły taką wielkość, iż najczęściej z powodów organizacyjnych ich sprzedaż odbywała się na więcej niż jednej aukcji, organizowanych w odstępach kilku miesięcy lub kilku lat. Zauważyć możemy także odwrotną sytuację: w trakcie jednej licytacji pod młotek licytatora trafiały księgozbiory, przeważnie o niedużej wielkości, zgromadzone przez kilka osób. Do ustalonej wielkości należy jeszcze dodać sześć księgozbiorów prywatnych licytowanych wraz ze zbiorami różnego pochodzenia, tzw. zbiorami anonimowymi. Łącznie aukcje bibliotek prywatnych dokumentuje obecnie 120 zachowanych katalogów, co stanowi 33\% wszystkich przeprowadzonych licytacji księgozbiorów domowych. W tym wypadku odsetek zachowanych katalogów jest większy niż dla tych rejestrujących licytacje zbiorów innego pochodzenia ${ }^{3}$.

Katalogi aukcyjne jako źródło do dziejów bibliotek prywatnych maja wiele zalet. Sa to, poza dwoma przypadkami, jedyne drukowane spisy książek z okresu staropolskiego, gdyż w Rzeczypospolitej - w odróżnieniu od wielu krajów europejskich - bardzo rzadko miejscowi kolekcjonerzy decydowali się na drukowanie katalogu bibliotecznego ${ }^{4}$. Tylko pięć ze 120 znanych dziś katalogów ma postać rękopiśmienna, ponieważ przepisy regulujące przebieg licytacji książkowych odbywających się w polskich miastach nakładały na ich organizatorów obowiązek publikowania spisów książek wystawianych na sprzedaż. Dostarczają też

2 Więcej o aukcjach w różnych miastach polskich w XVII i XVIII wieku zob. w: I. Imańska, Per medium auctionis. Aukcje ksiażek w Rzeczypospolitej (XVII-XVIII w.), Toruń 2013, s. 58-117 i 119-158.

3 W sumie w polskich i zagranicznych bibliotekach oraz archiwach zachowały się 162 katalogi aukcyjne, czyli z 23,5\% wszystkich znanych nam aukcji książek przeprowadzonych na ziemiach polskich od 1672 do $1800 \mathrm{r}$. Nie jest to wiele, ale podobny, a czasem nawet mniejszy procent zachowanych katalogów odnotowuja również badacze $\mathrm{w}$ innych krajach europejskich. Np. badacze holenderscy mają dostęp od $15 \%$ do $20 \%$ katalogów w zależności od miasta. Por.: Otto S. Lankhorst, Les ventes de livres en Hollande et leurs catalogues (XVIIe-XVIIIe siècles), [w:] Les ventes de livres et leurs catalogues XVIIe-XXe siècle, ed. by A. Charon, E. Parinet, Paris 2000, s. 15.

4 Znamy dwa takie przypadki: [Józef Aleksander A. Jabłonowski], Bibliotheca Jablonoviana, Leipzig 1755 i [Jacques Eggers], Bibliothèque militaire du GeneralMajor d'Eggers, Danzic 1771. 
o wiele dokładniejszych opisów bibliograficznych niż inwentarze rękopiśmienne. Tę sprawę również w kilku przypadkach poruszały regulaminy aukcyjne, w których zwracano uwagę na kompletność opisu, szczególnie na umieszczanie nazwisk autorów książek oraz adresu wydawniczego ${ }^{5}$. Nie znaczy to oczywiście, że każda zarejestrowana w katalogu książka da się dziś bez problemu zidentyfikować. Wbrew zapisom regulaminowym widnieją w nich dzieła z częściowo zniekształconym tytułem (skróconym lub podanym w wersji obiegowej), z niekompletną tytulatura, często pozbawione miejsca i roku wydrukowania czy po prostu z błędnym rokiem druku, wynikającym np. z prostej pomyłki drukarskiej. Podobnie jak w inwentarzach, zdarzają się też zapisy sumaryczne, typu: Varii tractatus medici variorum, czy Miscellanea, odnoszące się zwłaszcza do drobnych druków.

Katalogi aukcyjne są doskonałym źródłem przede wszystkim do poznania bibliotek mieszczańskich. Wynika to z faktu, że aukcje książek odbywały się w pierwszej kolejności w takich miastach jak: Gdańsk, Toruń i Elblag, w których bogate mieszczaństwo, profesorowie miejscowych szkół, duchowni protestanccy i wyżsi urzędnicy miejscy byli już w tym czasie właścicielami znacznych bibliotek. W pozostałych miastach, w których do końca XVIII w. pod młotek licytatora trafiały biblioteki prywatne, tylko sporadycznie ich właścicielami były osoby pochodzenia arystokratycznego. To źródło wyróżnia jeszcze jedna rzecz, mianowicie dostarczaja, poza kilkoma wyjątkami, informacji o księgozbiorach dość sporych, liczących od kilkuset do ponad 20 tysięcy książek. Aukcja książek była przedsięwzięciem wymagającym podjęcia wielu przygotowań, dlatego decydowano się na jej organizację wówczas, gdy do sprzedaży był znaczny lub wyjątkowo cenny zbiór. W innych przypadkach posiadane przez daną osobę książki wystawiane były na licytację obok pozostałego majątku ruchomego (np. ubrań, pościeli, obrazów, mebli itp.) przeznaczonego na sprzedaż.

Wykorzystując katalogi aukcyjne jako źródło do poznania dawnych bibliotek prywatnych, musimy zwrócić uwagę na kilka spraw. Taki katalog umożliwia rekonstrukcję księgozbioru prywatnego, w pewnym stopniu jest formą jego spisu inwentarzowego, mówi o stanie zachowania kolekcji. Jednak nasuwa się pytanie: w jakim zakresie jest to zbiór kompletny? Inaczej mówiąc: czy wystawiona na publiczną sprzedaż kolekcja objęła wszystkie książki i czasopisma, które skompletowała dana osoba? Licyta-

5 Por. Barbara Serczykowa, Pierwszy stały regulamin aukcji ksiażek w Toruniu z 1718 roku, [w:] Zeszyty Naukowe UMK w Toruniu, Nauka o Książce 4, Nauki Hum.Społ., z. 18, Toruń 1966, s. 27. 
cje bibliotek prywatnych odbywały się z różnych powodów. Najczęstszym była śmierć właściciela biblioteki i wynikająca stąd potrzeba podziału jego majątku między spadkobierców; czasami pieniądze uzyskane ze sprzedaży książek przeznaczano na pokrycie kosztów nauki jego małoletnich synów. Kolejnym powodem była przeprowadzka, która stanowiła okazję do dokonania czegoś w rodzaju selekcji zebranego majątku, w tym książek, i wybrania tych najpotrzebniejszych, pozostałe przeznaczono zaś na sprzedaż. Zdarzało się też, że właściciel biblioteki znalazł się w tarapatach finansowych, które z kolei doprowadzały do wyprzedaży dóbr nakazem sądowym. Niezależnie od przyczyny aukcji nie jesteśmy dziś w stanie stwierdzić, czy wszystkie zebrane przez daną osobę książki stały się jej przedmiotem, czy tylko część zbiorów, jak w wypadku przenosin do innego miasta. Kilka przykładów dowodzi, że bardziej prawdopodobna jest ta druga możliwość. Nietrudno sobie wyobrazić, że rodzina po śmierci kolekcjonera, nawet gdy spadkobiercy posiadali już własne ciekawe zbiory, wybierała z pozostawionej biblioteki jakieś książki bądź ze względu na ich wartość merytoryczną czy materialną, bądź z powodów sentymentalnych, jako pamiątkę po zmarłym przodku. Czasem sam właściciel w testamencie decydował o losie kolekcji, przeznaczając jej część wskazanej przez siebie instytucji. Tak postapił na przykład gdańszczanin Walenty Schlieff, osoba o zainteresowaniach historycznych, który zgromadził księgozbiór liczący około dziewięciu tysięcy druków i rękopisów. Te dotyczące Gdańska, Polski i Prus Królewskich przekazał Bibliotece Senatu Gdańskiego, co zgodnie z jego życzeniem nastapiło po wygaśnięciu rodziny, w 1782 r. Pozostały zbiór trafił na aukcję po śmierci jego syna Walentego Leona w 1752 roku$^{6}$. Również tylko część księgozbioru tzw. Kleiniano-Gralathiana, gromadzonego przez członków dwóch rodów: prawnika i przyrodnika Jakuba Teodora Kleina i jego zięcia, także przyrodnika, Daniela Gralatha starszego, dostała się pod młotek licytatora. Po śmierci Gralatha biblioteka przypadła jego synowi, a wnukowi Kleina, Danielowi Gralathowi młodszemu, który jako historyk i prawnik miał odmienne zainteresowania od dziadka i ojca. Dlatego w 1772 r. książki z zakresu matematyki i przyrody zdecydował się zbyć poprzez aukcję . Podobnie nie wszystkie zbiory Jana Daniela Hof-

${ }^{6}$ Elżbieta Piotrowska, Gdańskie kolekcje biblioteczne XVI-XVIII wieku w zbiorach Biblioteki Gdańskiej PAN, „Gdański Rocznik Kulturalny”, 12:1989, s. 64. Katalog z tej aukcji niestety nie zachował się.

7 Tamże, s. 64-65. Katalog aukcyjny znajduje się w zbiorach PAN Biblioteka Gdańska, sygn. Aa $144218^{\circ}$, adl. 1 ([Jacob Theodor Klein, Daniel Gralath], Pars bibliothecae Kleinio-Gralathianae, quae complectitur apparatum librorum ad historiam naturalem spectantium, philosophicorum et mathematicorum, juncta collectione itinerariorum studio historiae naturalis praecipue inservientium, Gedani 1772). 
fmanna, zmarłego w 1766 r. profesora gimnazjum elbląskiego, znalazły się w ofercie aukcji zorganizowanej w Elblagu dwa lata po jego śmierci ${ }^{8}$. Wiemy, że jakaś część książek i wiele dokumentów rękopiśmiennych należących do Hoffmanna było do nabycia w $1821 \mathrm{r}$. na licytacji biblioteki Jana Schmidta, spadkobiercy tego fragmentu majątku elbląskiego konrektora9 ${ }^{9}$ Mamy też przykłady spoza Prus Królewskich świadczące o tym, że nie cała kolekcja książek wystawiana była na publiczną sprzedaż. Możemy to zaobserwować w przypadku księgozbioru rodziny Sułkowskich, za twórcę którego uważa się żyjącego w latach 1695-1762 Aleksandra Józefa Sułkowskiego, ministra króla Augusta III. Istotny wpływ na rozwój i charakter kolekcji miał jego syn, August (1729-1786), marszałek Rady Nieustającej, interesujący się również sprawami szkolnictwa i kultury. On w 1776 r. utworzył ordynację Sułkowskich, przebudował w Rydzynie starą pomarańczarnię z przeznaczeniem na muzeum, bibliotekę i galerię obrazów ${ }^{10}$. August Sułkowski i jego brat Aleksander pozostawili ogromne długi, dlatego następny ordynat, Antoni Sułkowski, uzyskawszy zgodę sejmu w 1788 r. sprzedał część majątku. Kolejna wyprzedaż dóbr nastapiła po jego śmierci. W końcu w 1798 r. odbyła się w Lesznie licytacja ruchomości rydzyńskich, trwająca półtora miesiąca. Objęła ona również poważny fragment biblioteki pałacowej. Zachowany katalog aukcyjny rejestruje ponad 2660 pozycji o różnej treści ${ }^{11}$. Nie był to cały księgozbiór, gdyż dobytek rodziny Sułkowskich, w tym książki, był w ostatnich latach XVIII wieku jeszcze co najmniej dwa razy przedmiotem licytacji: od 14 V 1799 r. i od 4 VI następnego roku ${ }^{12}$. Także tylko część książek zebranych przez generała majora Ignacego Działyńskiego (1754-1797) została wystawiona na licytację w jego byłym domu na Lesznie w Warszawie w październiku 1800 r. Infor-

8 Katalog tej aukcji znajduje się obecnie w zbiorach Biblioteki Narodowej w Warszawie, sygn. . XVIII.1.3851: [Johann Daniel Hoffmann], Catalogus bibliothecae b. Jo. Dan. Hoffmanni, quondam conrectoris et prof. publ. gymnasii Elbigensis celeberrimi optimeque meriti libris selectis theologicis, philosophicis, historicis, litterariis alisque instructae ac publica auctionis lege d. 3. Febr. anni 1768. [rz.] pro parata pecunia in aedibus quas dum viveret inhabitavit b. vir in platea vulgo $\mathrm{H}$. Geist. Gasse sitis distrahendae, Elbingae [1768].

9 Lidia Pszczółkowska, Jan Daniel Hoffmann (1701-1766), profesor gimnazjum, historyk, historyk drukarstwa, bibliograf, [w:] Wybitni Pomorzanie XVIII wieku. Szkice biograficzne, Wrocław 1983, s. 83.

10 Dorota Dukwicz, Michał Zwierzykowski, Sułkowski August, PSB, t. 45/4, z. 187, 2008, s. 544, 546, 551.

${ }_{11}$ [Aleksander Józef Sułkowski], Catalogus der Auctionis lege den 24ten October et seqq. a. c. allhier zu Lissa zu veraußernden zur Fürstl. von Sulkowskischen Majorats Nachlassenschaft gehörigen Bibliotheque, Lissa 1798 (egzemplarze w zbiorach: BJ sygn. 587847, i BUWr - sygn. 374983).

12 Ogłoszenia o planowanych licytacjach zamieszczono w „Gazecie Warszawskiej”, 1799, nr 27 z 2 IV (dodatek) i 1800, nr 37 z 9 V (dodatek). 
macje zamieszczone w anonsach prasowych o przeznaczonych na sprzedaż książkach sugerują, że był to zbiór sporej wielkości, składający się z dzieł francuskich (w tym była także Wielka encyklopedia francuska), łacińskich i polskich, wśród których było sporo pozycji kosztownych i rzadkich ${ }^{13}$. Zapewne w warszawskim pałacu generał umieścił swą główną bibliotekę. Jak wielu arystokratów, książki posiadał również w swoich innych majątkach, np. niewielki zbiór, liczący 117 tomów, znajdował się w jego posiadłości we wsi Szumska na Wołyniu ${ }^{14}$.

W trakcie przeglądania katalogów aukcyjnych napotykamy często na kolejny problem: w niektórych z nich, po podstawowym spisie książek (ułożonym zazwyczaj według formatów, sporadycznie z podziałem na dziedziny wiedzy lub według dni licytacji) występują dodatki, określane zwykle jako appendix bądź, gdy katalog był redagowany w języku niemieckim, Anhang. Niełatwo jest dziś stwierdzić, skąd pochodziły książki spisane w tej części katalogu. Pod uwagę możemy brać kilka możliwości: mogły to być pozycje wcześniej pominięte, np. z powodu pośpiesznego przygotowywania spisu lub zwrócenia później pożyczonych książek, jednak w kilku wypadkach użyto wtedy precyzyjnego sformułowania Libri omissi. Takie rozwiązanie spotykamy np. w katalogu zawierającym wykaz książek po gdańskim pastorze Janie Falcku, przygotowanym na aukcję zaczynającą się 17 IV 1730 r., gdzie w Libri omissi odnotowane zostało siedem książek formatu folio i sześć w formacie octavo ${ }^{15}$. Nieco więcej książek ( $26 \mathrm{w}$ „dwójce” i $53 \mathrm{w}$ „,czwórce”) pod takim określeniem zarejestrowała osoba przygotowująca katalog w 1794 r. na licytację księgozbioru po Wilhelmie Pawle Verpoortenie, rektorze gdańskiego Gimnazjum Akademickiego ${ }^{16}$. Bardziej prawdopodobne wydaje się, że licytator, korzystając z okazji, „wzbogacał” konkretną aukcję książka-

${ }^{13}$ Por. „Gazeta Warszawska”, 1800, nr 76 z 23 IX (dodatek) i „Allgemeine LiteraturZeitung", 1800, nr 136.

14 Marian J. Lech, Księgozbiór generałostwa Działyńskich, [w:] „Z Badań nad Polskimi Księgozbiorami Historycznymi”, t. 5, Warszawa 1981, s. 139-146.

15 [Johann Falck], Catalogus librorum viri Maxime quondam Reverendi atq. Amplissimi Dn. Joann. Falckii V. D. M. Semi-Secularis, et Pastoris ad Aedem, S. Catharinae dicatam dum viveret, meritissimi, quos solenni ac consveto auctionis ritu et jure in aedibus pastoralibus, in platea, a mola sic dicta, vulgo Kleinen MühlenGasse sitis, anno 1730, d. 17 April publice parata pro pecunia distrahendos curabit Joann. Ottmerson. Gedani [1730] (Katalog w zbiorach Książnicy Cieszyńskiej, sygn. SZ SIX 15, 2).

16 [Wilhelm Paul Verpoorten], Reliquiae bibliothecae Ver Poortennianae. Acc. anonymianae particula. Uterque librorum adparatus a. d. 19.[rz.] Maii seqv.1794 [rz.] in adedibus a B. Dno. Rectore Gymnasii inhabitatis (vulgo auf dem Klosterhofe) auctionis lege publice distrahetur per Car. Gust. Dinnies, Gedani [1794] (katalog w zbiorach Biblioteki Uniwersyteckiej w Getyndze, sygn. 8 HLL XI, 784). 
mi pochodzącymi z innych źródeł, np. pozostałościami po poprzednich publicznych wyprzedażach. Za możliwością stosowania takiej praktyki przemawia uwaga uczyniona przez toruńską radę miejską, która udzielając zgody na przeprowadzenie drugiej $\mathrm{w}$ dziejach miasta licytacji księgozbioru prywatnego, zastrzegła, aby do katalogu rejestrującego spuściznę biblioteczną po pastorze Janie Reinholdzie Böhmie nie dołączać jako Appendix wykazu obcych książek, zakazała również mieszać ich z książkami Böhma ${ }^{17}$. Nic nie wiemy o podobnych wattpliwościach w stosunku do zamieszczanych uzupełnień w innych miastach, w których organizowane były licytacje książkowe. W zachowanych katalogach aukcyjnych na różnego rodzaju dodatki natrafiamy, przeglądając katalogi z aukcji bibliotek prywatnych przeprowadzanych w Gdańsku, Toruniu, a także w Warszawie. W wielu przypadkach spisane zostało w nich niewiele książek, od kilku do kilkudziesięciu, co może sugerować, że były to druki wcześniej pominięte, ale zdarzały się dodatki z osobną paginacja, kilkustronicowe, zawierające wykaz nawet powyżej trzystu dzieł, do tego treściowo zdecydowanie odbiegających od zainteresowań zawodowych właściciela licytowanej kolekcji. Jako przykład może posłużyć dodatek występujący pod nazwą Librorum selectorum, umieszczony na dwunastu osobno numerowanych stronach w katalogu rejestrującym bibliotekę gdańskiego pastora Idziego Straucha, wystawioną na sprzedaż w 1685 r. Strauch był właścicielem bogatej kolekcji książek, liczącej ponad trzy i pół tysiąca pozycji. We wspomnianym dodatku odnotowanych zostało 349 tytułów o różnej treści ${ }^{18}$. Natomiast do katalogu przygotowanego na aukcję książek w 1719 r. po innym gdańskim pastorze, Janie Joachimie Wende, dołączony został wykaz określony jako Librorum medicorum z 74 pracami z tego zakresu ${ }^{19}$. Tylko raz gdy dołączono dodatek z wykazem 433 pozycji do katalogu z drugiej licytacji bogatego, w dużym stopniu specjalistycznego księgozbioru po Karolu Beniaminie Lengni-

17 Toruń, AP, Acta consularia, sygn. Kat. II, II 21, k. 74v-75.

18 [Aegidius Strauch], Catalogus librorum bibliothecae locupletissimae, summe quondam Reverendi, Amplissimi atque excellentissimi viri Dni. Aegidii Strauchii, b. M. S. S. Theologiae Doctoris, ejusdemque professoris publici, pastoris ecclesiae ad S. S. Trinit. vigilantissimi, illustris Gymnasii Gedanensis Rectoris meritissimi, theologi, philosophi, mathem. chronolog. historici celeberrimi, quos publica auctione Q. F. F. S. consveto ritu ac jure divendet, Ernestus Barckman, a die 30. [rz.] Julii. Anno 1685 [rz.], Gedani [1685] (egzemplarz w zbiorach Saksońskiej Państwowej i Uniwersyteckiej Biblioteki w Dreźnie, sygn. 3.A.9743, angeb.).

${ }_{19}$ [Jacob Joachim Wend], Catalogus bibliothecae Jac. Joach. Wendii, ministri quondam verbi divini ad aedem S. S. Trinit. fidelissimi, publica auctionis lege venalis, quem sexta Martii a.c. 1719 [rz.] in aedibus a pie defuncto inhabitatis horis consvetis distrahet Georgius Mattern, Gedani [1719] (katalog w zbiorach BN, sygn. XVIII. 2.3795). 
chu, wyraźnie zaznaczono, że mieści on książki niebędące własnością gdańskiego duchownego ${ }^{20}$.

Jak wspomniałam wyżej, ustalenie pochodzenia książek wykazywanych w dodatkach jest dziś bardzo trudne. W kilku przypadkach dotyczących licytacji książkowych przeprowadzonych w Gdańsku w XVIII stuleciu ten problem udało się rozwiązać. Pomógł w tym fakt, że dana aukcja udokumentowana była różnymi przekazami źródłowymi. $\mathrm{Z}$ ich konfrontacji (zachowanego katalogu aukcyjnego, anonsów w prasie i archiwaliów) wyraźnie widać, że w załączonych do katalogu dodatkach krył się najczęściej niewielkich rozmiarów inny księgozbiór prywatny. Była to zapewne praktyka dość często stosowana przez miejscowych aukcjonatorów, którzy, mając do zbycia zbiór liczący kilkadziesiąt książek, wystawiali go na sprzedaż w drugiej kolejności, po większej bibliotece, która ze względu na ciekawą ofertę lub nazwisko znanego kolekcjonera była gwarancją powodzenia całego przedsięwzięcia. Taka sytuacja zaistniała w mieście nad Motławą na początku stycznia 1783 r., gdy pod młotek licytatora, a był nim wówczas Karol Gustaw Dinnies, trafiło około 200 książek po Johannie Gottlobie Holzapfelu. W Archiwum Państwowym w Gdańsku w dokumentach dotyczących sprzedaży pozostawionych po nim dóbr zachował się drukowany wykaz tych książek, zatytułowany Appendix ${ }^{21}$. Zaś anons zapowiadający licytację książek tego dnia, zamieszczony na łamach „Wöchentliche Danziger Anzeigen und dienliche Nachrichten", informował, że na chętnych czekają dzieła dobre i nowe, w tym holenderskie, wydania rzymskich klasyków, prace z zakresu prawa, teologii, medycyny, także tomiki poezji i muzykalia ${ }^{22}$. Analiza zawartości zachowanego dodatku do katalogu nie potwierdza treści ogłoszenia prasowego, stąd można wnioskować, że najpierw jako główny sprzedawany był zbiór książek anonsowany w gazecie, a po nim - książki Holzapfela. Niestety, nie wiemy, kto był właścicielem księgozbioru opisywanego w ogłoszeniu, nie zachował się też jego kata-

20 [Karl Benjamin Lengnich], Bibliotheca Lengnichiana, a Dno Car. Benj. Lengnich archidiacono ad templum B. Mariae Virg. dum viveret meritissimo collecta. Sectio prima a. d. 3.[rz.] Octobris sequ. 1796 [rz.] (sectio secunda a. d. 31. [rz.] Octobris sequ. 1796 [rz.]) in aedibus quas pie defunctus inhabitavit (in der Frauengasse, von der Pfarrkirche kommend rechter Hand im 2ten Hause) auctionis lege publice distrahenda, per Car. Gustav. Dinnies, Gedani [1796]. Wspomniany dodatek to: Anhang von Büchern, welche nach beendigter Auction der Bibliothek des Wohlseel. Hrn. Archidiac. Lengnich noch ausgerufen werden sollen und zur Verlassenschaft desselben nicht gehören. (niekompletny katalog w zbiorach Ossolineum we Wrocławiu, sygn. XVIII-12503-II- cz. 1; całość, cz. 1-2 posiada Biblioteka Królewska Szwecji, sygn. 107 E 21).

${ }^{21}$ Gdańsk, AP, Akta miasta Gdańska: Urząd Prezydującego Burmistrza, sygn. 300, $1 / 163$, s. 409-555.

22 „Wöchentliche Danziger Anzeigen und dienliche Nachrichten”, 1782, nr 52. 
log. Z podobną sytuacją mamy do czynienia w przypadku licytacji zapowiadanej w prasie na 20 IX 1784 r. także bez podania nazwiska właściciela biblioteki ze wskazaniem jedynie, że na kupujących czekają w dużej części nowe książki ${ }^{23}$. I tu również po wyprzedaży książek, o których informowało ogłoszenie prasowe, do sprzedaży była jeszcze spora partia (804 pozycje) kolejnych dzieł. W zbiorach Archiwum zachował się rękopiśmienny spis książek zatytułowany „Catalogo von derer Büchern zum Nachlass der verb. seel. Johann Nicolaus Zimmermann" oraz jego wersja drukowana, występująca tylko pod lakonicznym tytułem Appendix zum Catalogus vom 20. Sept. 1784, wraz z rozliczeniem z aukcji książek, przeprowadzonej właśnie 20 IX 1784 r., podpisanym przez aukcjonatora Samuela Bogumiła Fischera ${ }^{24}$.

Wymienione tu przykłady oraz praktyka dołączania w postaci dodatku księgozbiorów o niedużej wielkości do licytowanych większych kolekcji, stosowana przez aukcjonatorów gdańskich, pokazuja, że pod hasłem „Appendix” kryła się często oferta niemająca związku ze zbiorem stanowiącym podstawę aukcji.

Podany wyżej przykład wskazuje na jeszcze jeden problem. Otóż bardzo wiele licytacji książkowych, które odbywały się szczególnie w drugiej połowie XVIII wieku w Gdańsku i w Warszawie, to licytacje tzw. zbiorów anonimowych, nieznanego lub różnego pochodzenia. Tak było, gdy licytator skupował mniejsze partie książek od różnych osób, by po zgromadzeniu odpowiedniej wielkości zbioru wystawić je na publiczną sprzedaż. Katalogi z takich aukcji oczywiście w tytulaturze nie mają ujawnionego właściciela licytowanych książek. I tym razem konfrontacja kilku źródeł pokazała, że nie zawsze licytujący mieli do czynienia z książkami różnego pochodzenia, mimo że i na kartach tytułowych drukowanych katalogów aukcyjnych, i czasami nawet w anonsach prasowych powiadamiających o licytacjach z nieznanych nam powodów pomijane było nazwisko właściciela kolekcji przeznaczonej na sprzedaż. Można zrozumieć, że tak postępował organizator aukcji, gdy wystawiał na publiczna sprzedaż nieduży i być może niezbyt interesujący zbiór książek, a do tego nazwisko ich właściciela nie było na tyle znane, aby stać się zachętą dla potencjalnych uczestników licytacji. W końcu kwietnia 1779 r. gdański aukcjonator Samuel Bogumił Fischer przeprowadził licytację 153 książek głównie treści teologicznej i historycznej, uzupełnionych o kilka rysunków i map miedziorytowych, pomijając na karcie tytułowej katalogu

${ }^{23}$ „Wöchentliche Danziger Anzeigen und dienliche Nachrichten”, 1784, nr 38 z 18 IX.

24 Gdańsk, AP, sygn. 300,1/164, s. 443, ss. 405-420 to [Johann Nicolaus Zimmermann], Appendix zum Catalogus vom 20. Sept. 1784, [Gdańsk 1784]. Spis rękopiśmienny jest na stronach 421-436. 
aukcyjnego nazwisko właściciela tej niewielkiej kolekcji. Katalog ten obecnie znajduje się w Archiwum Państwowym w Gdańsku w zespole Akta Prezydującego Burmistrza. Prócz drukowanego katalogu jest tam także jego wersja rękopiśmienna $\mathrm{z}$ wymienionym w tytule nazwiskiem właściciela książek, którym był bliżej nieznany Jan Gotfryd Linde, oraz inne dokumenty zawierające spis pozostałych ruchomości i rozliczenia $\mathrm{z}$ ich sprzedaży ${ }^{25}$.

Ale trafiały się przypadki znacznie bogatszych księgozbiorów, a do tego należących do osób powszechnie znanych, których nazwiska zostały pominięte $\mathrm{w}$ tytulaturze. Jednym $\mathrm{z}$ nich był burmistrz toruński Michał Willer, właściciel prawie 800 książek poddanych licytacji w Toruniu w 1723 r. Na karcie tytułowej wydrukowanego na tę okazję katalogu pominięte zostało jego nazwisko, poinformowano jedynie, że licytowane będą książki różnego rodzaju. Rzecz wyjaśniają dopiero dokumenty z posiedzeń rady miejskiej, zachowane w Archiwum Państwowym w Toruniu. Na jej posiedzeniu w dniu 26 VII 1723 r. wydana została zgoda na przeprowadzenie aukcji książek pozostawionych przez wspomnianego burmistrza, zmarłego w grudniu 1722 roku. $^{26}$

Dzięki archiwaliom, tym razem gdańskim, odpowiedziano na pytania o właścicieli księgozbiorów opisanych w dwóch ,anonimowych” katalogach dokumentujących aukcje książek przeprowadzonych w mieście nad Motławą kolejno w 1774 i 1785 r. Jedyne egzemplarze obu drukowanych spisów znajdują się w Archiwum gdańskim w zespole oznaczonym sygnaturą 300,6, zawierającym dokumenty Urzędu Sędziego Głównego Miasta, w tym spisy ruchomości wystawianych na licytacje. Za każdym razem drukowane katalogi z aukcji książek dołączone zostały do rachunków i różnych rękopiśmiennych wykazów innych licytowanych mobiliów. W obu przypadkach na karcie tytułowej wzmiankowanych katalogów pominięte zostało nazwisko właściciela przeznaczonych na sprzedaż książek. W 1774 r. chodziło o 716 książek i ciekawy zbiór medali i monet należących do Chrystiana Fryderyka Schaukircha, które wystawiono na

${ }_{25}$ Gdańsk, AP, sygn. 300, 1/157, s. 197-216. Drukowany katalog aukcyjny: [Johann Gottfried Linde], Verzeichniß einer Sammlung von histor. theologischen und vielen andern Büchern, nebst dem Systema Copernicanum, welche den 28. April 1779 in der Tischler-Gasse vom Graben linker Hand im ersten verauctionirt werden sollen von Samuel Gottlieb Fischer, Danzig [1779], jest na s. 213-216.

26 Toruń, AP, sygn. Kat. II, II 27, k. 144. Katalog aukcyjny: [Michael Willer], Catalogus librorum varii generis publica auctione pro parata pecunia Thorunii in aedibus Marwitzianis in platea vulgo dicta Culmische Gasse sitis die 30. Septembr. 1723. [rz.] distrahendorum, Thorunii [1723] znajduje się w zbiorach Wojewódzkiej Biblioteki Publicznej - Książnicy Kopernikańskiej w Toruniu, sygn. A-54 (4) adl. 32. 
sprzedaż na jednej aukcji wyznaczonej na dzień 3 stycznia ${ }^{27}$. Dnia 7 listopada 1785 r. przedmiotem licytacji było aż 1649 książek, w większości zaopatrzonych w solidne oprawy, zebranych przez Jana Bogumiła Schnaase $^{28}$.

Dwie zagadki krył w sobie natomiast katalog wydany pod tytułem $\mathrm{Ve}$ rzeichniss einer Sammlung verschiedener in die Geschichte, Oeconomie und besonders in die Cameral-Wissenschaft einschlagenden Bücher, wobey durch ein Anhang von medicin. und chirurgischen Büchern, welche sämtlich auf Nachgeben es. hochedl. Richterl. Amts der Rechten Stadt Freytag den 7. May 1790 in der Frauen-und Kuhgassen Ecke Kirchwerts, an die Meistbietenden verauctioniret werden sollen durch $S$. G. Fischer, (Danzig [1790] ${ }^{29}$. Jak widać, organizator aukcji i tym razem pominą nazwisko właściciela książek. W tym drukowanym spisie najpierw w kolejności według formatów wymienionych zostało 675 pozycji, a następnie w dodatku (Anhang) kolejne 132. W podstawowym wykazie znajdowały się głównie książki opublikowane w XVIII wieku, w większości zaopatrzone w oprawy. Był to zbiór dość ciekawy: z dominacją literatury świeckiej, dużą liczbą poloników dotyczących Gdańska i prowincji pruskiej oraz z wieloma tytułami czasopism. Na Anhang składały się przede wszystkim książki o treści medycznej. Z analizy zawartości katalogu można było sądzić, że licytowane książki mogły należeć do dwóch osób. W ustaleniu właścicieli tych zbiorów ponownie pomogły archiwalia. Przechowywane są tam bowiem rozliczenia poaukcyjne, podpisane przez aukcjonatora S. B. Fischera, dotyczące sprzedaży księgozbioru w dniu 4 V 1790 r., który należał do Daniela Gabriela Konopacka ${ }^{30}$. Kilkanaście stron dalej znajdują się różne dokumenty dotyczące sprzedaży dóbr ruchomych należących do chirurga Jana Ernesta Bludowskiego. W spisie posiadanych przez niego rzeczy znajdowały się także książki, zbiory graficzne i ciekawa kolekcja naturaliów. Jak zwykle bywało, cały majątek

27 Gdańsk, AP, Archiwum miasta Gdańska: Urząd Sędziego, sygn. 300,6/161, s. 419-442. Katalog: [Christian Friedrich Schaurkirch], Verzeichniß von theologischen, juristischen und historischen Büchern, nebst einer Sammlung verschiedener größtentheils seltener goldener und silberner Medaillen, Thaler und anderer auch römischer Münzen welche den 3. Jeuner 1774. in dem Träger-Hause in der Jopengasse durch Ausruf verkaufet werden sollen von Samuel Gottlieb Fischer, Danzig [1774], jest na stronach s. 431-442.

28 Gdańsk, AP, sygn. 300, 6/174, s. 109-136. Katalog: [Johann Gottlieb Schnaase], Verzeichniß einer Samlung sehr wohl conditionirter Bücher, welche den 7ten November 1785 auf dem 4ten Damm in dem Eckhause an der Hökergasse verauktioniret werden sollen durch Sam. Gottl. Fischer, Danzig [1785], znajduje się na stronach 121-136.

29 Katalog obecnie znajduje się w zbiorach Biblioteki Gdańskiej, sygn. od $206958^{\circ}$.

${ }^{30}$ Gdańsk, AP, sygn. 300, 6/183, s. 61. 
został rozsprzedany na aukcjach. Rachunek za przygotowanie i przeprowadzenie aukcji książek podaje jej datę na 7 maja $^{31}$. Zbieżność dat obu licytacji (Konopacka i Bludowskiego) oraz zainteresowania Bludowskiego, o których możemy wnioskować na podstawie spisów jego majątku, i tematyka książek zarejestrowanych w dodatku do katalogu pozwalają sądzić, że to jego kolekcja była licytowana po książkach Konopacka.

Praktyka stosowana przez gdańskich aukcjonatorów nie była obca głównemu licytatorowi warszawskiemu, Michałowi Gröllowi. Od 6 VIII 1778 r. przystapił on mianowicie do wyprzedaży 2176 woluminów w trakcie jedenastu sesji aukcyjnych. Z karty tytułowej katalogu aukcyjnego opublikowanego z tej okazji dowiadujemy się jedynie, że na uczestników licytacji czekają różnej treści oprawione książki ${ }^{32}$. Jednocześnie na kilka dni przed rozpoczęciem wyprzedaży został zamieszczony anons na łamach „Gazety Warszawskiej”, w którym poinformowano, że właśnie 6 sierpnia u Grölla w Marywilu zacznie się licytacja biblioteki, której właścicielem był zmarły w poprzednim roku prymas Gabriel Jan Podoski ${ }^{33}$. Prymas był postacią kontrowersyjną: sprzeciwy budziły jego poglądy, postępowanie i życie osobiste. Podoski zmarł w Marsylii, gdzie osiadł kilka miesięcy przed śmiercią. Żył ponad stan i narobił długów. W Marsylii w $1787 \mathrm{r}$. na licytację zostały wystawione pozostałe po nim rzeczy

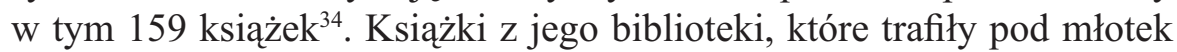
licytatora warszawskiego, to $\mathrm{w}$ dużym stopniu literatura świecka, z bogatym zestawem współczesnych autorów francuskich i angielskich wraz z głównym dziełem Oświecenia, Wielka encyklopedia francuska. Sądzę, że zbieżność dat, a do tego charakter treściowy licytowanej kolekcji potwierdzają, iż wystawione na publiczną sprzedaż książki były własnością Podoskiego.

Przedstawione przykłady pokazuja, że katalogi aukcyjne jako jedno ze źródeł do poznania bibliotek prywatnych kryją w sobie sporo niespodzianek. Praktyki stosowane przez organizatorów licytacji książkowych nie zawsze ułatwiają zadanie współczesnym badaczom. Udzielenie odpowiedzi na wiele pytań i rozwiązanie licznych niewiadomych umożli-

31 Gdańsk, AP, sygn. 300, 6/183, s. 91 - rachunek za aukcję książek, s. 79-89rachunki z licytacji innych dóbr Bludowskiego.

32 [Gabriel Podoski], Catalogus omnis generis librorum compactorum, qui auctionis publicae ritu, et praesenti pecunia aliorum usibus concedentur per Michael Gröll. reg. auctionator privil. Auctio fiet Varsaviae in Marievilla D. 6. et seqq. Augusti 1778. Hor. pomerid. 2-7.[rz.], Varsavie [1778] (egzemplarz katalogu w zbiorach Biblioteki Uniwersyteckiej w Toruniu, sygn. Pol. 8. II. 3615).

33 „Gazeta Warszawska”, 1778, nr 61, z 1 VIII (suplement).

34 Emanuel Rostworowski, Podoski Gabriel Jan, PSB, t. 27, Wrocław 1983, s. 149 , 160 . 
wia dopiero konfrontacja katalogów z innymi przekazami źródłowymi, co - niestety - nie w każdym wypadku jest wykonalne. Warto jednak podjąć poszukiwania zwłaszcza w materiale archiwalnym, gdyż dzięki dodatkowym dokumentom można wyjaśnić niektóre $\mathrm{z}$ nasuwających się watpliwości. Ważne jest też dokładne przyjrzenie się katalogom, na kartkach których został spisany tzw. zbiór anonimowy. I tu czasami okazuje się, że licytacji poddane zostały książki i czasopisma zebrane przez jedną osobę, na której nazwisko natrafiamy dopiero po dotarciu do innych przekazów źródłowych.

\section{Streszczenie}

\section{Kilka uwag i spostrzeżeń o katalogach aukcyjnych jako źródle do badań księgozbiorów prywatnych}

Spośród źródeł wykorzystywanych do poznania czytelnictwa i kolekcjonerstwa książek w dawnych czasach należy zwrócić baczną uwagę również na katalogi aukcyjne. Na ziemiach polskich aukcje książek pojawiły się w latach 70 . XVII w. w Gdańsku, a w następnym stuleciu znane i stosowane były w wielu miastach Rzeczypospolitej. Do końca XVIII w. przeprowadzono prawie 700 licytacji książek, z których około połowa to były aukcje bibliotek prywatnych. Aukcjom książek towarzyszył katalog aukcyjny, z reguły w postaci drukowanej. Obecnie w polskich i zagranicznych bibliotekach i archiwach znajduje się 120 tych spisów. Są one bardzo wartościowym źródłem umożliwiającym poznanie dawnych bibliotek prywatnych, w większości już nieistniejących, lub zachowanych w rozproszonych fragmentach. Ich interpretacja czasami stwarza jednak pewne problemy. Rodzą się np. pytania, czy kolekcja książek wystawiona na publiczną sprzedaż objęła całość zbiorów zgromadzonych przez daną osobę, czy książki wykazane $\mathrm{w}$ dodatkach umieszczonych w wielu katalogach na ich końcu należały do właściciela licytowanej biblioteki, czy też były własnością innej osoby. Te i inne problemy pomaga czasami rozwiązać konfrontacja katalogów aukcyjnych z innymi przekazami źródłowymi, jak anonse prasowe i przede wszystkim zachowane archiwalia.

Slowa kluczowe: aukcje książek - katalogi aukcyjne - biblioteki prywatne anonse prasowe - archiwalia. 
Summary

\section{Several remarks concerning auction catalogues as source materials for research on private book collections}

Among the sources that enable researching readership and book collecting in the former centuries auction catalogues are the materials that require careful scrutiny. On Polish territories, first book auctions appeared the sixteen-seventies in Gdańsk, and then in other cities of the Commonwealth. Until the end of the $18^{\text {th }}$ century, nearly 700 auctions took place, approximately half of which concerned books from private collections. The preparations for an auction encompassed compiling a catalogue, usually published in printed form. 120 such auction catalogues are extant in Polish and foreign archives. They provide excellent data concerning private libraries, chiefly either no longer existent or available in dispersed fragments. Nevertheless, the interpretation of these sources can be difficult. They beg questions such as: was the collection put on auction as a whole? were the books in the appendices to the catalogues parts of the auctioned collection, or did they belong to somebody else? Sometimes, these questions can be answered thanks to other sources like press advertisements, and above all by archival materials.

Key words: book auctions - auction catalogues - private libraries - press advertisements - archival materials. 